\title{
Identification of 23 TGFBR2 and 6 TGFBR1 Gene Mutations and Genotype-phenotype Investigations in 457 Patients with Marfan Syndrome Type I and II, Loeys-Dietz Syndrome and Related Disorders
}

\author{
Chantal Stheneur $^{1,2,3}$, Gwenaëlle Collod-Béroud ${ }^{4,5}$, Laurence Faivre ${ }^{6,7}$, Laurent Gouya ${ }^{2,8,9,10}$, \\ Gilles Sultan $^{2,11}$, Jean-Marie Le Parc ${ }^{2,10,12}$, Bertrand Moura ${ }^{2,12}$, David Attias ${ }^{2,10}$, Christine Muti ${ }^{2,8}$, \\ Marc Sznajder $^{1}$, Mireille Claustres ${ }^{4,5,13}$, Claudine Junien ${ }^{8,10,14}$, Clarisse Baumann ${ }^{15}$, \\ Valérie Cormier-Daire ${ }^{14,16}$, Marlène Rio ${ }^{14,16}$, Stanislas Lyonnet ${ }^{14,16}$, Henri Plauchu ${ }^{17}$, Didier Lacombe ${ }^{18}$, \\ Bertrand Chevallier ${ }^{1,2,10}$, Guillaume Jondeau ${ }^{2,19,20}$, and Catherine Boileau ${ }^{2,8,10,14}$
}

1: AP-HP, Hôpital Ambroise Paré, Service de Pédiatrie, Boulogne, F-92100 France. 2: AP-HP, Hôpital Bichat, Consultation multidisciplinaire Marfan, Paris, F-75018 France. 3: INSERM, U747, Paris, F-75005 France. 4: INSERM, U827, Montpellier, F-34000 France. 5: Université Montpellier1, Montpellier, F-34000 France. 6: CHRU Dijon, Centre d'Investigation Clinique-Epidémiologie-Cliniquelessais cliniques, Dijon, F-21000 France. 7: CHRU Dijon, Centre de Génétique, Dijon, F-21000 France. 8: AP-HP, Hôpital Ambroise Paré, Laboratoire Central de Biochimie d'Hormonologie et de Génétique moléculaire, Boulogne, F-92100 France. 9: INSERM, U793, Paris, F-75018 France. 10: Université Versailles-SQY, Versailles, F-78000 France. 11: AP-HP, Hôpital Ambroise Paré, Service d'Ophtalmologie, Boulogne, F-92100 France. 12: AP-HP, Hôpital Ambroise Paré, Service de Rhumatologie, Boulogne, F-92100 France. 13: CHU Montpellier, Laboratoire de Génétique Moléculaire, Montpellier, F-34000 France. 14: INSERM, U781, Hôpital Necker_Enfants-Malades, Paris, F-75015 France. 15: AP-HP, Hôpital Robert Debré, Département de Génétique, Paris, F-75019 France. 16: AP-HP, Hôpital Necker-Enfants-Malades, Département de Génétique médicale, Paris, F-75015 France. 17: Hôtel Dieu, Service de Génétique, Lyon, F-69000 France. 18: CHU de Bordeaux, Département de Génétique clinique, Bordeaux, F-33800 France. 19: AP-HP, Hôpital Bichat, Service de Cardiologie, Paris, F-75018 France. 20 : INSERM, U698, Paris, F-75018 France.

*Correspondence to C.Stheneur, MD., Ph.D., Service de Pédiatrie, Hôpital Ambroise Paré, 9 Avenue Charles de Gaulle 92100 Boulogne, France. Tel +331 49095705 : Fax +331 49095895 ; E-mail : chantal.stheneur@apr.aphp.fr Contract grant sponsor: GIS-Maladies Rares 2004; ANR-05-PCOD-014, Université Versailles Saint Quentin (Legs de Melle Bonnevie); Assistance publique-Hôpitaux de Paris (CIRC 2007) ; French Society of Cardiology and French Federation of Cardiology.

TGFBR1 and TGFBR2 gene mutations have been associated with Marfan syndrome types 1 and 2, Loeys-Dietz syndrome and isolated familial thoracic aortic aneurysms or dissection. In order to investigate the molecular and clinical spectrum of TGFBR2 mutations we screened the gene in 457 probands suspected of being affected with Marfan syndrome or related disorders that had been referred to our laboratory for molecular diagnosis. We identified and report 23 mutations and 20 polymorphisms. Subsequently, we screened the TGFBR1 gene in the first 74 patients for whom no defect had been found, and identified 6 novel mutations and 12 polymorphisms. Mutation-carrying probands displayed at referral a large clinical spectrum ranging from the Loeys-Dietz syndrome and neonatal Marfan syndrome to isolated aortic aneurysm. Furthermore, a TGFBR1 gene mutation was found in a Shprintzen-Goldberg syndrome patient. Finally, we observed that the yield of mutation detection within the two genes was very low : $4.8 \%$ for classical MFS, $4.6 \%$ for incomplete MFS and $1 \%$ for TAAD in the TGFBR2 gene; $6.2 \%, 6.2 \%$ and $7 \%$ respectively in the TGFBR1 gene; in contrast to LDS, where the yield was exceptionally high (87.5\%). 


\section{INTRODUCTION}

Alterations of TGF $\beta$ signaling through mutations (essentially somatic) in the TGFBR2 gene were associated with various cancers until our team reported germline mutations in the gene associated with Marfan syndrome (Mizuguchi, et al., 2004). Marfan syndrome (MFS; MIM\# 154700) is an inherited autosomal dominant disorder of connective tissue with an estimated incidence of 1/5.000 live births with more than $25 \%$ sporadic cases. MFS is characterized by a broad range of clinical manifestations involving skeletal, ocular, cardiovascular, skin and integument, pulmonary and central nervous systems with great phenotypic variability (Judge and Dietz, 2005). Cardiovascular involvement in the form of aortic aneurysm or dissecting aorta is the most serious life-threatening aspect of the syndrome and can be prevented by timely cardiovascular surgery. More than $90 \%$ of MFS cases are caused by mutations in the FBN1 gene encoding fibrillin-1, the major component of microfibrils. We mapped a second locus (MFS2) at 3p25-p24.2 (Collod, et al., 1994) in a large French family with autosomal dominant MFS not linked to the FBN1 gene. We subsequently showed that all affected family members carried a mutation in the TGFBR2 gene that altered proper splicing of intron 6 (Mizuguchi, et al., 2004). Shortly after, Loeys et al. (Loeys, et al., 2005) reported a new syndrome, caused by mutations in TGFBR1 or TGFBR2: the Loeys-Dietz Syndrome (LDS). MFS and LDS share several symptoms, including aortic root aneurysm and skeletal abnormalities (Loeys, et al., 2006). TGFBR2 mutations were also detected in patients with familial thoracic aortic aneurysms or dissections (TAAD) (Pannu, et al., 2005). These reports showed that a spectrum of diseases are associated with mutations in these genes, reminiscent of the situation known for mutations carried by the FBN1 gene that are grouped under the term of "type 1 fibrillinopathies". Similarly, mutations in the TGF $\beta$ receptor genes may be associated with a variety of "signalopathies", some still unrecognized (Boileau, et al., 2005). We report the findings of systematic sequencing of the TGFBR2 gene (followed in some cases by sequencing of the TGFBR1 gene) performed in consecutive proband samples addressed to our laboratory for molecular diagnosis of MFS and related disorders. We also describe the phenotypes associated with the mutations identified within the two genes.

\section{MATERIALS AND METHODS}

\section{Probands}

From 2004 to 2007, all new probands (202) addressed to our laboratory for molecular diagnosis of MFS and for whom no major ocular involvement had been found, were systematically screened at first for the presence of a mutation in the TGFBR2 gene. We also included in the screening 143 probands previously studied but negative for a FBN1 gene mutation, regardless of their clinical presentation, and 100 TAAD probands (TAAD was defined as major cardiac involvement alone) in whom FBN1 screening had not been performed. Secondarily, the first 62 probands negative for a TGFBR2 gene mutation were screened for a mutation in the TGFBR1 gene (25 new probands without major ocular involvement, 18 patients negative for a FBN1 gene mutation regardless of their clinical presentation, 14 TAAD, 3 LDS and 2 neonatal Marfan syndrome negative for a FBN1 gene mutation). Finally, the TGFBR2 and TGFBR1 genes were both tested in 12 additional probands presenting with related and overlapping diseases (see below for details). Thus a total of 457 probands were investigated. Probands (essentially of Caucasian European descent) originated from all over the national territory since our laboratory is the first French national reference laboratory for diagnosis of Marfan syndrome. Informed consent was obtained for all subjects in agreement with the French bioethic laws. The majority of patients were referred by the Multidisciplinary Marfan Clinic of our University Hospital. There, patients are evaluated by geneticists, rheumatologists or pediatricians (depending on their age), cardiologists, and ophthalmologists. Systematic slitlamp examination, cardiac ultrasonography, and radiological investigations are also performed. For samples referred from other centers, the clinical data of patients were routinely collected before mutation screening, but complete clinical data were not always available. For the purpose of this study, all clinical data were reassessed by one physician (C.S.), using the Ghent criteria, to ensure homogeneity of clinical data across centers. Some samples had been addressed to the laboratory before the description of LDS. In these cases, the clinical picture was reevaluated for this study with available clinical data. All aspects of LDS were looked for (hypertelorism, cleft palate, uvula, aortic aneurysm, all craniofacial and skeletal features, velvety skin, translucent skin, atrial septal defect and developmental delay), but for arterial tortuosity and aneurysms of vessels other than the aorta that were not recognized at the time of the original clinical assessment . 
For the purpose of this study, the probands tested have been subdivided into LDS, neonatal MFS (defined by severe valvular involvement before 4 weeks of age, associated with arachnodactyly, joint hypermobility, \pm joint contractures, loose skin, \pm ectopia lentis), probable MFS (defined by incomplete Ghent criteria in childhood, i.e. $<18$ years), incomplete Marfan (for patients with incomplete Ghent criteria in adulthood but with at least one system involved with a major criterion and one with a minor criterion), TAAD, Ectopia Lentis (EL) or skeletal involvement only, non MFS (defined by only minor involvement in one or more systems) and classical MFS (defined by positive Ghent criteria whatever the age). Finally, to better investigate the spectrum of phenotypes overlapping MFS, a group of 12 probands presenting with either Weil-Marchesani (WMS), Lujan Fryns, Shprintzen Goldberg (SGS) syndromes or Ehlers-Danlos (EDS) vascular type were screened for mutations in the TGFBR2 and TGFBR1 genes. All these disorders were diagnosed using recognized criteria (Beighton, et al., 1998; Faivre, et al., 2003; Fryns and Buttiens, 1987; Greally, et al., 1998).

\section{Mutation analysis}

Genomic DNA was isolated from peripheral blood leukocytes by standard procedures. We amplified all exons covering the TGFBR1 and TGFBR2 coding region by PCR for direct sequencing. Primers used for TGFBR2 have been reported previously (Mizuguchi, et al., 2004). New primers were designed for TGFBR1 and are available on request. Unidirectional sequencing for quick screening of the gene followed by bidirectional sequencing of altered exons was carried out (Big Dye terminators kit, ABI 3100 Genetic Analyzer, Applied Biosystems, Warrington, Cheshire, UK). When the mutation altered the regional restriction map, the presence of the mutation was also checked by PCR/digestion using the appropriate restriction enzyme. Nucleotide numbering reflects cDNA numbering with +1 corresponding to the A of the ATG translation initiation codon in the reference sequences (TGFBR2: NM_003242.5; TGFBR1:NM_004612.2). The initiation codon is codon 1.

\section{Prediction of the functional effect of amino acid substitution}

To assess the deleterious effect of identified sequence variants, we used various algorithms [among which are Polymorphism Phenotyping (PolyPhen); Sorting Intolerant From Tolerant (SIFT), Biochemical values and BLOSUM 62] which were developed to predict whether or not a variant is likely to affect protein function. All are implemented in the new version of UMD-LSDB software in the "UMD-Predictor" tool, kindly provided by Dr. C. Béroud (manuscript submitted).

\section{Statistical analysis}

Statistical analyses were performed using SPSS software version 12.0. The yield of mutation detection in probands with involvement in each separate organ system was compared by the Pearson chi-square test, or Fisher's exact test for small samples. A $p$ value of $<0.05$ was considered significant.

\section{RESULTS}

\section{TGFBR2 mutation analysis}

In the set of 457 patients, 23 mutations (19 novel, since 4 have already been reported in Mizuguchi et al (Mizuguchi, et al., 2004)) were identified in the TGFBR2 gene (overall success rate 5\%) and 20 polymorphisms. Mutations are shown in Fig.1 and described in Table 1, polymorphisms are given in Table 2. Each mutation affects a highly conserved nucleotide, is predicted as damaging protein production or affecting protein function, is absent in more than 200 subjects (400 chromosomes from unrelated French non MFS subjects addressed for molecular diagnosis) and, fully segregates in the family (for familial cases). All mutations but one are located between exons 4 to 7. Mutation types are distributed as follows: 17 missense mutations, 4 nonsense mutations, 1 splice-site alteration (p.Gln508Gln) and 1 deletion. The clinical presentations (according to the referring physician) of the 445 French probands studied was the following (Fig 2A): 8 LDS, 18 neonatal MFS and, 419 suspected of being MFS. Using recognized diagnostic criteria, probands from this last group were re-classified as: 105 classical MFS (53 with an ectopia lentis), 131 incomplete MFS (adults), 100 TAAD, 2 EL, 1 skeletal involvement only, 13 probable MFS (children) and 67 non MFS. Incomplete MFS are distributed as follows: 107 (81\%) have one major involvement in the cardiac system, 20 (15\%) major involvement in the ocular system, 21 (15.9\%) major 
involvement in the skeleton, 59 (44.7\%) involvement in integument, 10 (7.5\%) involvement in pulmonary system. Finally, 6 autosomal dominant WMS and negative for a FBN1 gene mutation, 1 Lujan Fryns, 2 SGS and 3 EDS vascular type were also included.

Clinical features of probands carrying a mutation in TGFBR2 are summarized in Table 1. Among the 8 LDS probands, 5 carried a TGFBR2 mutation and among the 18 neonatal MFS, 2 harbored a mutation. Finally, among 13 children screened for probable MFS, mutations were found in 3 children. In the 406 adult probands referred to our laboratory for molecular diagnosis of Marfan syndrome, 6 mutations were found among the 105 probands fulfilling the Ghent criteria for diagnosis of MFS (mutation detection rate of 5.7\%), 6 mutations were found among the 131 reclassified as incomplete MFS (mutation detection rate of 4.6\%) and 1 among the 100 TAAD. It should be noted that no mutation was found among the 12 probands with overlapping syndromes (Lujan-Fryns, SGS, WMS and EDS).

Since our overall mutation detection rate was very low and our study population was clinically very heterogeneous, we tried to identify specific isolated or combined system involvements that were more frequently associated with a TGFBR2 gene mutation. The results of this study are shown in Table 3. Only cardiac involvement was significantly different between the 2 groups, being more frequent in the TGFBR2 positive patients than in the TGFBR2 negative patients. When TGFBR2 positive patients were compared to FBN1 positive patients (Faivre, et al., 2007), more frequent cardiac involvement and less frequent ectopia lentis were found.

\section{TGFBR1 mutation analysis}

We screened the TGFBR1 gene in a subset of 74 probands (the first 62 probands negative for a TGFBR2 mutation and the 12 probands with overlapping syndromes). In this subset of probands, 4 new and two recurrent mutations were identified (Fig.1) and 12 polymorphisms were detected. Mutations and polymorphisms are described in Tables 4 and 2, respectively. Each mutation affects a highly conserved nucleotide, is predicted as damaging protein production or affecting protein function, is absent in more than 200 subjects ( 400 chromosomes from unrelated French non MFS subjects addressed for molecular diagnosis) and, fully segregates in the family (in the two familial cases). All mutations are in exon 4 but for one in exon 6. Mutation types are for five a missense mutation and for one a deletion.

The distribution of patients in this subset was the following (Fig 2B): 3 TGFBR2 negative LDS, 2 neonatal MFS, 16 classical MFS, 9 non MFS, 16 incomplete MFS (adults), 14 TAAD, 1 EL and 1 probable MFS (child.

For mutated patients in the subset, distribution of diagnosis at referral was the following: 2 LDS, 1 classical MFS, 1 incomplete MFS, 1 patient with TAAD and interestingly, 1 SGS. Clinical features of probands carrying a mutation in TGFBR1 are also summarized in Table 4. It should be noted that all mutation-carrying probands display major cardiac involvement. Furthermore, for the incomplete MFS and the classical MFS probands features of LDS were looked for but none was found. 


\section{TGFBR2}

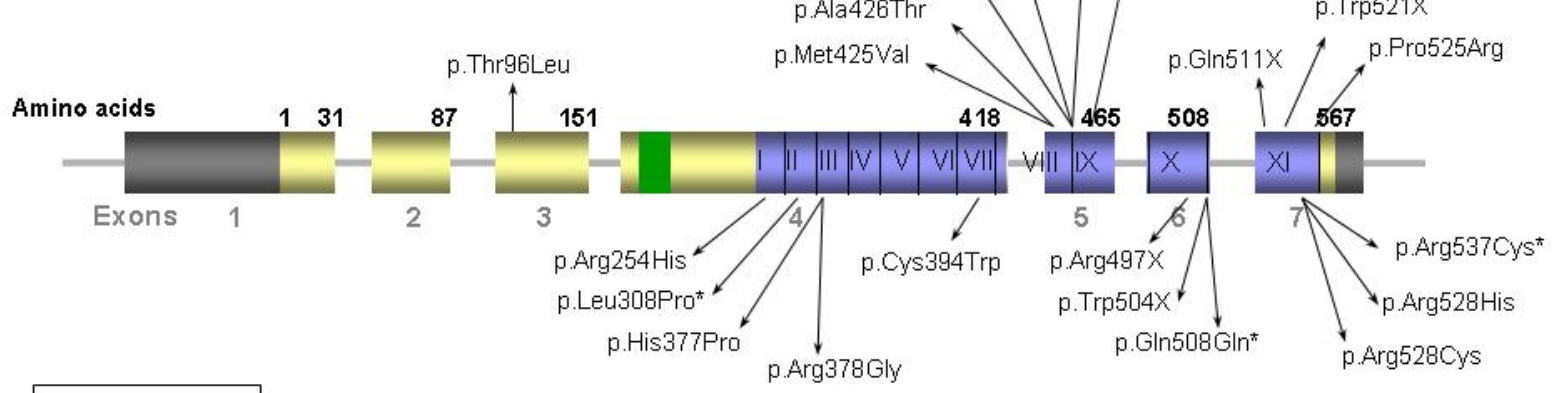

\section{TGFBR1}

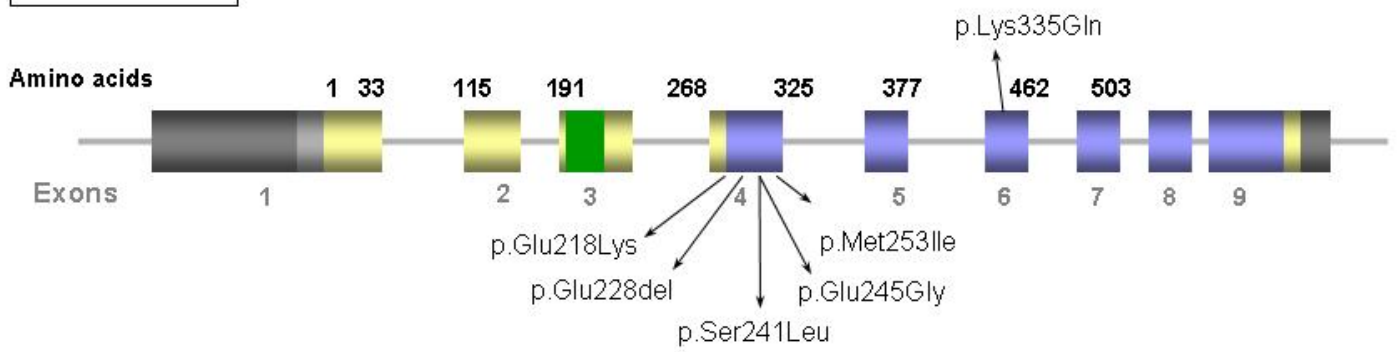

Figure 1: Mutations in the TGFBR2 and the TGFBR1 genes found in our study.

The different exons are numbered. The colored boxes represent the exons encoding the extracellular domain of the receptor (yellow), the transmembrane domain (green) and, the serine-threonine kinase domain (blue). *Mutation previously described by our team ((Mizuguchi, et al., 2004)). The p.Arg537Arg mutation is recurrent and was identified in 3 non related probands. 
Table 1: Patients with mutations in the TGFBR2 gene

\begin{tabular}{|c|c|c|c|c|c|c|c|c|c|c|c|c|c|c|}
\hline $\begin{array}{l}\text { Diagnosis at } \\
\text { referral }\end{array}$ & $\begin{array}{c}\text { Age } \\
\text { (years) }\end{array}$ & Exon & Nucleotide & Protein & Sex & $\mathrm{CS}$ & OS & SS & S & PS & NS & $\begin{array}{l}\text { LDS specific } \\
\text { symptoms }\end{array}$ & \begin{tabular}{c|} 
Inheritan \\
ce
\end{tabular} & $\begin{array}{l}\text { Recurrence and diagnosis in } \\
\text { previous studies }\end{array}$ \\
\hline LDS & 38 & 4 & c. $1182 \mathrm{C}>\mathrm{G}$ & p. Cys394Trp & $\bar{F}$ & $\mathrm{M}$ & - & - & - & - & - & Hypertelorism & Familial & - \\
\hline LDS & 7 & 5 & c. $1336 \mathrm{G}>\mathrm{C}$ & p. Asp446His & $\mathrm{F}$ & $\mathrm{M}$ & - & - & - & - & $?$ & $\begin{array}{c}\text { Bifid uvula } \\
\text { Camptodactyly }\end{array}$ & de novo & - \\
\hline LDS & 26 & 5 & c. $1336 \mathrm{G}>\mathrm{A}$ & p. Asp446Asn & $\mathrm{F}$ & $\mathrm{M}$ & - & $\mathrm{m}$ & $\mathrm{m}$ & - & $?$ & - & de novo & $\begin{array}{c}\text { Probable MFS [Disabella et } \\
\text { al., 2006] }\end{array}$ \\
\hline LDS & 1 & 5 & c.1351_1356del & $\begin{array}{c}\text { p. Ala451_L452 } \\
\text { del }\end{array}$ & $\mathrm{M}$ & $\mathrm{M}$ & - & - & - & - & - & $\begin{array}{l}\text { Bifid uvula } \\
\text { Chiari type I }\end{array}$ & de novo & - \\
\hline LDS & 9 & 7 & c. $1583 \mathrm{G}>\mathrm{A}$ & p. Arg528His & $\mathrm{M}$ & $\mathrm{M}$ & $\mathrm{m}$ & - & $?$ & $?$ & $?$ & $\begin{array}{l}\text { Chiari type I } \\
\text { Cleft palate } \\
\text { Talipes } \\
\text { equinovarus } \\
\end{array}$ & de novo & LDS [Loeys et al., 2005] \\
\hline $\begin{array}{c}\text { Neonatal } \\
\text { MFS/LDS** }\end{array}$ & 0 & 4 & c. $1130 \mathrm{~A}>\mathrm{C}$ & p. His377Pro & $\mathrm{M}$ & $\mathrm{M}$ & - & - & - & - & $?$ & \begin{tabular}{c|} 
Talipes \\
equinovarus \\
Camptodactyly \\
\end{tabular} & de novo & - \\
\hline $\begin{array}{c}\text { Neonatal } \\
\text { MFS/LDS** }\end{array}$ & 0 & 7 & c. $1582 \mathrm{C}>\mathrm{T}$ & p. Arg528Cys & $\mathrm{M}$ & $\mathrm{M}$ & - & $\mathrm{M}$ & - & - & $?$ & $\begin{array}{c}\text { Bifid uvula } \\
\text { Hypertelorism }\end{array}$ & de novo & $\begin{array}{l}\text { LDS [Loeys et al., 2005] } \\
\text { LDS [Lemaire et al.,2007] }\end{array}$ \\
\hline Probable MFS & 13 & 5 & c. $1346 \mathrm{C}>\mathrm{T}$ & p. Ser449Phe* & $\mathrm{F}$ & $\mathrm{M}$ & - & $\mathrm{M}$ & - & - & - & $\begin{array}{c}\text { Patent ductus } \\
\text { arteriosus } \\
\text { Atrial septal } \\
\text { defect } \\
\end{array}$ & Familial & $\begin{array}{l}\text { LDS [Loeys et al., 2006] } \\
\text { IM [Mizuguchi et al., 2004] }\end{array}$ \\
\hline Probable MFS & 7 & 7 & c. $1531 \mathrm{C}>\mathrm{T}$ & p. Gln511X & F & $\mathrm{M}$ & - & $\mathrm{m}$ & - & - & $?$ & - & Familial & - \\
\hline Probable MFS & 3 & 7 & c. $1574 \mathrm{C}>\mathrm{G}$ & p. Pro525Arg & $\bar{F}$ & $\mathrm{M}$ & - & $\mathrm{m}$ & - & - & $?$ & - & de novo & - \\
\hline TAAD & 46 & 7 & c. $1609 \mathrm{C}>\mathrm{T}$ & p. Arg537Cys & $\mathrm{M}$ & $\mathrm{M}$ & - & - & - & - & $?$ & - & Familial & $\begin{array}{l}\text { LDS [Loeys et al., 2006] } \\
\text { IM [Akutsu et al., 2007] } \\
\text { IM [Mizuguchi et el., 2004] }\end{array}$ \\
\hline IM & 26 & 4 & c. $761 \mathrm{G}>\mathrm{A}$ & p. Arg254His & $\mathrm{M}$ & $\mathrm{M}$ & - & - & $\mathrm{m}$ & - & $?$ & - & NM & - \\
\hline$\overline{\mathrm{IM}}$ & & 5 & c. $1276 \mathrm{G}>\mathrm{A}$ & p. Ala426Thr & $\mathrm{M}$ & $\mathrm{M}$ & - & $\mathrm{m}$ & $?$ & $\mathrm{~m}$ & $?$ & Bifid uvula & de novo & - \\
\hline IM & 33 & 6 & c. $1489 \mathrm{C}>\mathrm{T}$ & p. $\operatorname{Arg} 497 X$ & $\mathrm{M}$ & $\mathrm{M}$ & - & $\mathrm{M}$ & - & - & $?$ & - & Familial & MFS [Singh et al., 2006] \\
\hline IM & 43 & 6 & c. $1511 \mathrm{G}>\mathrm{A}$ & p. Trp504X & $\mathrm{F}$ & - & $\mathrm{M}^{\S}$ & $\mathrm{M}$ & - & - & $?$ & Bifid uvula & Familial & - \\
\hline IM & 33 & 7 & c. $1609 \mathrm{C}>\mathrm{T}$ & p. Arg537Cys* & $\mathrm{M}$ & $\mathrm{M}$ & - & $\mathrm{m}$ & $\mathrm{m}$ & - & - & - & Familial & IM [Mizuguchi et al., 2004] \\
\hline IM & 36 & 7 & c. $1609 \mathrm{C}>\mathrm{T}$ & p. Arg537Cys & $\bar{F}$ & $\mathrm{M}$ & - & $\mathrm{m}$ & $\mathrm{m}$ & $\mathrm{m}$ & $?$ & - & Familial & - \\
\hline MFS & 38 & 3 & c. $287 \mathrm{C}>\mathrm{T}$ & p. Thr96Ile & $\mathrm{F}$ & $\mathrm{M}$ & $\mathrm{M}^{\S}$ & - & $\mathrm{m}$ & - & $?$ & - & Familial & - \\
\hline MFS & 18 & 4 & c. $923 \mathrm{~T}>\mathrm{C}$ & p. Leu308Pro* & $\mathrm{F}$ & $\mathrm{M}$ & $\mathrm{m}$ & $\mathrm{M}$ & $\mathrm{m}$ & - & $?$ & - & de novo & MFS [Mizuguchi et al., 2004] \\
\hline MFS & 28 & 4 & c. $1132 \mathrm{~A}>\mathrm{G}$ & p. Arg378Gly & $\mathrm{F}$ & $\mathrm{M}$ & - & $\mathrm{m}$ & $\mathrm{m}$ & - & $\mathrm{M}$ & - & de novo & - \\
\hline MFS & 26 & 5 & c. $1273 \mathrm{~A}>\mathrm{G}$ & p. Met425Val & $\mathrm{M}$ & $\mathrm{M}$ & - & $\mathrm{m}$ & $\mathrm{m}$ & - & $\mathrm{M}$ & - & Familial & MFS [Disabella et al., 2006] \\
\hline MFS & 48 & 6 & c. $1524 \mathrm{G}>\mathrm{A}$ & p. Gln508Gln* & F & $\mathrm{M}$ & - & $\mathrm{m}$ & $\mathrm{m}$ & - & $\mathrm{M}$ & - & Familial & MFS [Mizuguchi et al., 2004] \\
\hline MFS & 25 & 7 & c. $1562 \mathrm{G}>\mathrm{A}$ & p. Trp521X & $\mathrm{M}$ & $\mathrm{M}$ & - & $\mathrm{m}$ & $\mathrm{m}$ & $\mathrm{m}$ & $\mathrm{M}$ & - & de novo & \\
\hline
\end{tabular}

M: major criterion fulfilled, m: minor criterion fulfilled, - : organ system not involved, ?: not mentioned.

CS: Cardiac system, OS: Ocular system, SS: Skeletal system, S: Skin and integument, PS: Pulmonary system, NS:

Neurological system

* Proband and mutation previously reported by our team

** Probands diagnosed at referral as probable neonatal MFS but displaying features now known to belong to the LDS spectrum

$\S$ The presence of ectopia lentis was identified and confirmed by slit lamp examination.

LDS: Loeys Dietz Syndrome. TAAD: Thoracic Aortic Aneurysm or Dissection. IM: Incomplete Marfan Syndrome. MFS:

Marfan Syndrome.

Nucleotide numbering reflects cDNA numbering with +1 corresponding to the A of the ATG translation initiation codon in the reference sequences (TGFBR2: NM_003242.5). The initiation codon is codon 1. 
Table 2 : Polymorphisms found in this study

\begin{tabular}{|c|c|c|c|c|}
\hline EXON & NUCLEOTIDE & WT CODON & $\begin{array}{c}\text { MUTATED } \\
\text { CODON }\end{array}$ & VARIATION \\
\hline \multicolumn{5}{|c|}{ TGFBR1 } \\
\hline 1 & c. $1-94 \mathrm{C}>\mathrm{T}$ & & & \\
\hline 1 & c.69_77delGGCGGCGGC & & & p.Ala23_Ala25delinsAla \\
\hline 3 & c. $574+50 \mathrm{C}>\mathrm{T}(\mathrm{c} . \mathrm{IVS} 3+50 \mathrm{C}>\mathrm{T})$ & & & \\
\hline 4 & c. $805+39 A>G($ c.IVS4+39A>G) & & & \\
\hline 5 & c.806-21insA (c.IVS4-21 insA) & & & \\
\hline 6 & c. $1125 \mathrm{~A}>\mathrm{C}$ & ACA & ACC & p.Thr375Thr \\
\hline 7 & c. $1255+24 \mathrm{G}>\mathrm{A}(\mathrm{c} . \mathrm{IVS} 7+24 \mathrm{G}>\mathrm{A})$ & & & \\
\hline 8 & c.1386+68A>G (c.IVS8+67AT>C) & & & \\
\hline 8 & $\begin{array}{l}\text { c.1386+90_1386+95 delTCTTT } \\
\text { (c.IVS8+90_+95 delTCTTT) }\end{array}$ & & & \\
\hline 9 & c. $1512 * 47 \mathrm{~A}>\mathrm{G}(\mathrm{STOP}+47 \mathrm{~A}>\mathrm{G})$ & & & \\
\hline 9 & c. $1512 * 60 \mathrm{~A}>\mathrm{G}(\mathrm{STOP}+60 \mathrm{~A}>\mathrm{G})$ & & & \\
\hline 9 & c.1512*138 insC (STOP+138 insC) & & & \\
\hline \multicolumn{5}{|c|}{ TGFBR2 } \\
\hline 1 & c. $1-128 \mathrm{C}>\mathrm{G}$ & & & \\
\hline 2 & c. $263+7 \mathrm{~A}>\mathrm{G}(\mathrm{c} . \mathrm{IVS} 2+7 \mathrm{~A}>\mathrm{G})$ & & & \\
\hline 4 & c.455-4T $>$ A (c.IVS3-4T $>$ A) & & & \\
\hline 4 & c. $999 A>G$ & CTA & CTG & p.Leu333Leu \\
\hline 4 & c. $1043 \mathrm{G}>\mathrm{A}$ & CGA & CAC & p.Arg348His \\
\hline 4 & c. $1062 \mathrm{C}>\mathrm{T}$ & CTC & CTT & p.Leu354Leu \\
\hline 4 & c. $1119 \mathrm{G}>\mathrm{A}$ & ATG & ATA & p.Met373Ile \\
\hline 4 & c. $1159 \mathrm{G}>\mathrm{T}$ & GTG & TTG & p.Val387Leu \\
\hline 4 & c. $1159 \mathrm{G}>\mathrm{A}$ & GTG & ATG & p.Val387Met \\
\hline 4 & c. $1167 \mathrm{C}>\mathrm{T}$ & $\mathrm{AAC}$ & AAT & p.Asn389Asn \\
\hline 4 & c. $1171 \mathrm{C}>\mathrm{T}$ & CTA & TTA & p.Leu391Leu \\
\hline 4 & c. $1191 \mathrm{C}>\mathrm{G}$ & GAC & GAG & p.Asp397Glu \\
\hline 4 & c. $1254+60 \mathrm{G}>\mathrm{A}(\mathrm{c} . \mathrm{IVS} 4+60 \mathrm{G}>\mathrm{A})$ & & & \\
\hline 5 & c. $1266 \mathrm{~A}>\mathrm{G}$ & GCA & GCG & p.Ala422Ala \\
\hline 5 & c. $1316 \mathrm{~T}>\mathrm{C}$ & GTT & GCT & p.Val439Ala \\
\hline 6 & c. $1524+62 A>G($ c.IVS6+62A $>$ G) & & & \\
\hline 6 & c. $1524+230 \mathrm{C}>\mathrm{G}(\mathrm{c} . \mathrm{IVS} 6+230 \mathrm{C}>\mathrm{G})$ & & & \\
\hline 6 & c. $1524+236 \mathrm{C}>\mathrm{T}(\mathrm{c} . \mathrm{IVS} 6+236 \mathrm{C}>\mathrm{T})$ & & & \\
\hline 7 & c. $1525-91 \mathrm{C}>\mathrm{A}(\mathrm{c} . \mathrm{IVS} 6-91 \mathrm{C}>\mathrm{A})$ & & & \\
\hline 7 & c. $1657 \mathrm{~T}>\mathrm{A}$ & TCG & ACG & p.Ser553Thr \\
\hline
\end{tabular}

Nucleotide numbering reflects cDNA numbering with +1 corresponding to the A of the ATG translation initiation codon in the reference sequences (TGFBR1: NM_004612.2; TGFBR2: NM_003242.5). The initiation codon is codon 1. 
A TGFBR2 gene screening

B TGFBRl gene screening
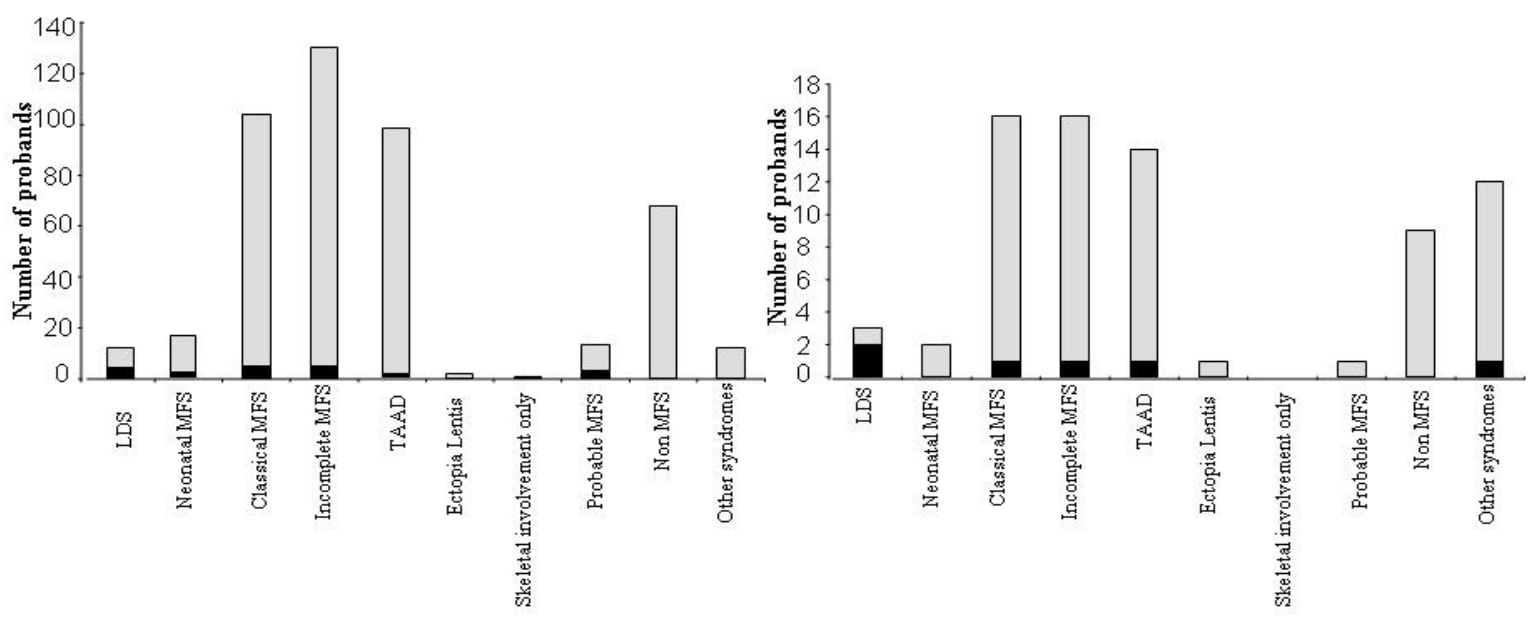

Figure 2: Distribution according to clinical presentation of probands screened for a mutation in the TGFBR2 and TGFBR1 genes. For each clinical type, number of probands with a gene mutation is given in black. LDS: Loeys-Dietz Syndrome. MFS: Marfan Syndrome. TAAD: Thoracic Aortic Aneurysm or Dissection.

Table 3: Comparison between probands carrying a TGFBR2 gene mutation, probands with no mutation identified in this gene and probands carrying a FBN1 gene mutation

\begin{tabular}{|l|c|c|c|l|c|}
\hline $\begin{array}{c}\text { Major system } \\
\text { involvement }\end{array}$ & $\begin{array}{c}\text { Probands } \\
\text { with a } \\
\text { TGFBR2 } \\
\text { mutation } \\
\mathbf{N = 2 3}\end{array}$ & $\begin{array}{c}\text { Probands with } \\
\text { no mutation in } \\
\text { the TGFBR2 } \\
\text { gene }\end{array}$ & $\begin{array}{c}\text { Comparison } \\
\text { between } \\
\text { probands with } \\
\text { and without } \\
\text { mutation in the } \\
\text { TGFBR2 gene }\end{array}$ & $\begin{array}{l}\text { Probands } \\
\text { with FBN1 } \\
\text { gene } \\
\text { mutation } \\
\text { [Faivre et al., } \\
\text { 2007] }\end{array}$ & $\begin{array}{c}\text { Comparison } \\
\text { between probands } \\
\text { with mutation in } \\
\text { the TGFBR2 gene } \\
\text { and in the FBN1 } \\
\text { gene }\end{array}$ \\
\hline Cardiac & $22 / 23$ & $286 / 373$ & $\mathrm{p}=0.036$ & $776 / 1013$ & $\mathrm{p}=0.041$ \\
\hline Ocular & $2 / 21$ & $72 / 306$ & $\mathrm{NS}$ & $542 / 1013$ & $\mathrm{p}=<0.0001$ \\
\hline Skeletal & $5 / 21$ & $90 / 326$ & $\mathrm{NS}$ & $327 / 1013$ & $\mathrm{NS}$ \\
\hline Neurological & $4 / 8$ & $32 / 63$ & $\mathrm{NS}$ & $154 / 292$ & $\mathrm{NS}$ \\
\hline $\begin{array}{l}\text { Skin and } \\
\text { integument }\end{array}$ & $10 / 21$ & $139 / 258$ & $\mathrm{NS}$ & $480 / 1013$ & $\mathrm{NS}$ \\
\hline Pulmonary & $3 / 22$ & $24 / 226$ & $\mathrm{NS}$ & $73 / 1002$ & $\mathrm{NS}$ \\
\hline
\end{tabular}


Table 4 :Patients with mutations in the TGFBR1 gene

\begin{tabular}{|c|c|c|c|c|c|c|c|c|c|c|c|c|c|c|}
\hline $\begin{array}{c}\text { Diagnosis } \\
\text { at } \\
\text { referral }\end{array}$ & $\begin{array}{l}\text { Age } \\
\text { (years) }\end{array}$ & Exon & Nucleotide & Protein & Sex & $\mathrm{CS}$ & OS & SS & $\mathrm{S}$ & PS & NS & $\begin{array}{l}\text { LDS specific } \\
\text { symptoms }\end{array}$ & Inheritance & $\begin{array}{c}\text { Recurrence and } \\
\text { diagnosis in previous } \\
\text { studies }\end{array}$ \\
\hline LDS & 19 & 4 & c.682_684delGAA & p.Glu228del & $\mathrm{M}$ & $\mathrm{M}$ & - & - & $?$ & $?$ & $\begin{array}{l}? \\
\end{array}$ & $\begin{array}{c}\text { Bifid uvula } \\
\text { Hypertelorism } \\
\text { scaphocephalie }\end{array}$ & de novo & - \\
\hline LDS & 13 & 4 & c. $722 \mathrm{C}>\mathrm{T}$ & p.Ser241Leu & $\mathrm{M}$ & $\mathrm{M}$ & $?$ & $?$ & $?$ & $?$ & $?$ & $\begin{array}{c}\text { Bifid uvula } \\
\text { Craniosynostosis } \\
\text { Developmental } \\
\text { delay } \\
\end{array}$ & de novo & $\begin{array}{c}\text { LDS [Matyas et al., } \\
2006] \\
\text { Furlong }{ }^{\Delta} \text { [Adès et al., } \\
2006]\end{array}$ \\
\hline SGS & 17 & 4 & c. $734 \mathrm{~A}>\mathrm{G}$ & p.Glu245Gly & $\mathrm{M}$ & M & - & - & - & - & ? & $\begin{array}{l}\text { Craniosynostosis } \\
\text { Hypertelorism } \\
\text { Retrognathia } \\
\text { Malar hypoplasia } \\
\text { Developmental } \\
\text { delay } \\
\end{array}$ & de novo & - \\
\hline MFS & 39 & 4 & c. $759 \mathrm{G}>\mathrm{A}$ & p.Met253Ile & $\mathrm{F}$ & $\mathrm{M}$ & - & $\mathrm{M}$ & $\mathrm{m}$ & - & $?$ & - & Familial & $\begin{array}{c}\text { MFS } \\
\text { [Singh et al., 2006] }\end{array}$ \\
\hline
\end{tabular}

$\mathrm{M}$ : major criterion fulfilled, $\mathrm{m}:$ minor criterion fulfilled, - : organ system not involved, ? : not mentioned.

CS : Cardiac system, OS : Ocular system, SS : Skeletal system, S : Skin and integument, PS : Pulmonary system, NS :

Neurological system

* Proband and mutation previously reported by our team

** Probands diagnosed at referral as probable neonatal MFS but displaying features now known to belong to the LDS spectrum

LDS : Loeys Dietz Syndrome. SGS : Shprintzen Goldberg Syndrome. TAAD : Thoracic Aortic Aneurysm or Dissection. IM : Incomplete Marfan Syndrome. MFS : Marfan Syndrome.

$\Delta$ Furlong syndrome is listed as LDS type 1A in OMIM

Nucleotide numbering reflects cDNA numbering with +1 corresponding to the A of the ATG translation initiation codon in the reference sequences (TGFBR1: NM_004612.2). The initiation codon is codon 1. 


\section{DISCUSSION}

Our study extends the spectrum of disease-causing TGFBR1 and TGFBR2 mutations in MFS-related disorders because of the large population studied. In 29 of 457 probands referred to our laboratory for molecular diagnosis of a pathology possibly associated with a TGF $\beta$ receptor defect or belonging to the spectrum of MFS and related disorders, we identified 23 mutations in the TGFBR2 gene and 6 in TGFBR1 (Fig.1).

In agreement with previous reports (Akutsu, et al., 2007; Loeys, et al., 2005; Matyas, et al., 2006; Mizuguchi, et al., 2004; Sakai, et al., 2006; Singh, et al., 2006), mutations in TGFBR2 were principally located in exons 4 to 7 that encode the intracellular kinase domain of the receptor. The only exception is the p.Thr96Ile mutation located in exon 3 where only heterozygous somatic mutations found in tumor samples, had been previously reported (Frederic, et al., 2008). The proband is a 38-year old female who had been examined after an aortic dissection. She presented with no skeletal signs but mild ectopia lentis and striae distensae. Her parents had normal cardiac echography, but her father also fully carried the mutation in his blood cells with no indication of the existence of a mosaicism. The p.Thr96Ile substitution was never observed in the very large series of subjects we have screened or in the series reported by other teams, thus excluding a polymorphism. Furthermore, the algorithms implemented in UMD-Predictor all predicted a deleterious effect. Therefore $\mathrm{p}$. Thr96Ile is likely to be responsible for the disease in the proband. Its detection in her father could reveal the existence of incomplete penetrance. Large variations of expression are associated with TGFBR2 mutations and we and others have already reported cases of incomplete penetrance in families (Matyas, et al., 2006; Mizuguchi, et al., 2004). Our present results could further strengthen these previous reports warranting cautious genetic counseling in families.

Mutations found in the TGFBR2 gene associated with connective tissue disorders are essentially missense and only rare instances of nonsense or deletions have been identified (Frederic, et al., 2008; Pannu, et al., 2005; Singh, et al., 2006). In our study, $26 \%$ of the probands had a mutation leading to a premature termination codon (PTC) whereas $74 \%$ had a mutation leading to an altered protein. However both classes seem evenly distributed between clinical presentations. Therefore, there does not seem to exist a direct relationship between the mutation type and the different pathogenic mechanisms underlying the various diseases investigated. This is further underscored by the existence of recurrent mutations such as p.Arg537Cys that is associated with TAAD as well as incomplete MFS in our study, and has also been identified in a LDS proband (Loeys, et al., 2006).

For the TGBFR1 gene, all mutations but one (in exon 6) are located in exon 4 that encodes the highly conserved kinase domain. All mutations previously described are also located in this domain, and preferentially located in exons 4 (10 mutations reported) and 9 (10 mutations reported) (G. Collod-Béroud, personnal communication). In our study, 5 mutations are missense, as all the 27 ones previously reported (Akutsu, et al., 2007; Loeys, et al., 2006; Matyas, et al., 2006; Sakai, et al., 2006; Singh, et al., 2006) (Unpublished data communicated for inclusion in the UMD databases curated by G. Collod-Béroud).

However, we also report the first deletion in the gene that we identified in a LDS proband (Table 4). Finally, contrary to what we observed for mutations in the TGFBR2 gene, mutations in TGFBR1 are fully penetrant in the two multiplex families that carry the p.Glu218Lys and p.Met253Ile (Table 4). It should be noted that the clinical spectrum of diseases with TGFBR1 mutations appears as large as that of TGFBR2 mutations with even a case of SGS. However, the p.Ser241Leu and p.Met253Ile TGFBR1 mutations found in 2 French probands are recurrent and associated with clinical symptoms highly comparable to those already reported (Ades, et al., 2006; Matyas, et al., 2006; Singh, et al., 2006).

The mutation identification rate in both genes was high in LDS probands since 7 mutations were identified for 8 French probands. It could be speculated that the missing mutation is in fact within one of the two genes since only sequencing of exons and flanking intronic regions were performed in our study. Thus, molecular diagnosis of LDS seems highly efficient and can be easily and quickly performed since both genes are relatively small. In contrast, for all other diseases we investigated, the overall mutation identification rate was very low for both genes. This is in agreement with previous reports since, to date and including our results, 34 mutations in TGFBR1 and 95 germline mutations in TGFBR2 have been identified worldwide (G. Collod-Béroud, personnal communication). Furthermore, in our study, the yield of TGFBR2 mutation identification in "non-FBN1" probands was 5.59\% (8/143). We cannot calculate the combined mutation detection rate because too few patients were screened for TGFBR1, but probably no greater than $10 \%$. In previous studies, the combined mutation rate was reported between 0 and 19\% (Akutsu, et al., 2007; Loeys, et al., 2005; Matyas, et al., 2006; Mizuguchi, et al., 2004; Sakai, et al., 2006; Singh, et al., 2006). When considering clinical types, non significant differences were found for mutation 
detection rates in the TGFBR2 gene between classic MFS and incomplete MFS probands. When considering system involvement, and despite a population selection bias in favor of minimal ocular manifestations, only 2 probands carrying a TGFBR2 gene mutation had ectopia lentis. Conversely, major cardiac involvement was almost always present (Table 3). Therefore, despite the ease and quickness of screening of the TGFBR2 gene, its yield is limited for molecular diagnosis in MFS as well as for TAAD probands. However, among patients with no ocular manifestation but presenting some features of LDS, screening of the TGFBR2 or TGFBR1 gene should be performed before screening the FBN1 gene.

\section{ACKNOWLEDGMENTS}

The authors thank all physicians who referred patients for diagnosis.

\section{REFERENCES}

Ades LC, Sullivan K, Biggin A, Haan EA, Brett M, Holman KJ, Dixon J, Robertson S, Holmes AD, Rogers J and others. 2006. FBN1, TGFBR1, and the Marfan-craniosynostosis/mental retardation disorders revisited. Am J Med Genet A 140(10):104758 .

Akutsu K, Morisaki H, Takeshita S, Sakamoto S, Tamori Y, Yoshimuta T, Yokoyama N, Nonogi H, Ogino H, Morisaki T. 2007. Phenotypic heterogeneity of Marfan-like connective tissue disorders associated with mutations in the transforming growth factor-beta receptor genes. Circ J 71(8):1305-9.

Beighton P, De Paepe A, Steinmann B, Tsipouras P, Wenstrup RJ. 1998. Ehlers-Danlos syndromes: revised nosology, Villefranche, 1997. Ehlers-Danlos National Foundation (USA) and Ehlers-Danlos Support Group (UK). Am J Med Genet 77(1):31-7.

Boileau C, Jondeau G, Mizuguchi T, Matsumoto N. 2005. Molecular genetics of Marfan syndrome. Curr Opin Cardiol 20(3):194-200.

Collod G, Babron MC, Jondeau G, Coulon M, Weissenbach J, Dubourg O, Bourdarias JP, Bonaiti-Pellie C, Junien C, Boileau C. 1994. A second locus for Marfan syndrome maps to chromosome 3p24.2-p25. Nat Genet 8(3):264-8.

Faivre L, Collod-Beroud G, Loeys BL, Child A, Binquet C, Gautier E, Callewaert B, Arbustini E, Mayer K, Arslan-Kirchner M and others. 2007. Effect of mutation type and location on clinical outcome in 1,013 probands with Marfan syndrome or related phenotypes and FBN1 mutations: an international study. Am J Hum Genet 81(3):454-66.

Faivre L, Dollfus H, Lyonnet S, Alembik Y, Megarbane A, Samples J, Gorlin RJ, Alswaid A, Feingold J, Le Merrer M and others. 2003. Clinical homogeneity and genetic heterogeneity in Weill-Marchesani syndrome. Am J Med Genet A 123(2):204-7.

Frederic MY, Hamroun D, Faivre L, Boileau C, Jondeau G, Claustres M, Beroud C, Collod-Beroud G. 2008. A new locusspecific database (LSDB) for mutations in the TGFBR2 gene: UMD-TGFBR2. Hum Mutat 29(1):33-8.

Fryns JP, Buttiens M. 1987. X-linked mental retardation with marfanoid habitus. Am J Med Genet 28(2):267-74.

Greally MT, Carey JC, Milewicz DM, Hudgins L, Goldberg RB, Shprintzen RJ, Cousineau AJ, Smith WL, Jr., Judisch GF, Hanson JW. 1998. Shprintzen-Goldberg syndrome: a clinical analysis. Am J Med Genet 76(3):202-12.

Judge DP, Dietz HC. 2005. Marfan's syndrome. Lancet 366(9501):1965-76.

Loeys BL, Chen J, Neptune ER, Judge DP, Podowski M, Holm T, Meyers J, Leitch CC, Katsanis N, Sharifi N and others. 2005. A syndrome of altered cardiovascular, craniofacial, neurocognitive and skeletal development caused by mutations in TGFBR1 or TGFBR2. Nat Genet 37(3):275-81.

Loeys BL, Schwarze U, Holm T, Callewaert BL, Thomas GH, Pannu H, De Backer JF, Oswald GL, Symoens S, Manouvrier S and others. 2006. Aneurysm syndromes caused by mutations in the TGF-beta receptor. N Engl J Med 355(8):788-98.

Matyas G, Arnold E, Carrel T, Baumgartner D, Boileau C, Berger W, Steinmann B. 2006. Identification and in silico analyses of novel TGFBR1 and TGFBR2 mutations in Marfan syndrome-related disorders. Hum Mutat 27(8):760-9. 
Mizuguchi T, Collod-Beroud G, Akiyama T, Abifadel M, Harada N, Morisaki T, Allard D, Varret M, Claustres M, Morisaki H and others. 2004. Heterozygous TGFBR2 mutations in Marfan syndrome. Nat Genet 36(8):855-60.

Pannu H, Tran-Fadulu V, Milewicz DM. 2005. Genetic basis of thoracic aortic aneurysms and aortic dissections. Am J Med Genet C Semin Med Genet 139(1):10-6.

Sakai H, Visser R, Ikegawa S, Ito E, Numabe H, Watanabe Y, Mikami H, Kondoh T, Kitoh H, Sugiyama R and others. 2006. Comprehensive genetic analysis of relevant four genes in 49 patients with Marfan syndrome or Marfan-related phenotypes. Am J Med Genet A 140(16):1719-25.

Singh KK, Rommel K, Mishra A, Karck M, Haverich A, Schmidtke J, Arslan-Kirchner M. 2006. TGFBR1 and TGFBR2 mutations in patients with features of Marfan syndrome and Loeys-Dietz syndrome. Hum Mutat 27(8):770-7. 